\title{
Before the Revolution: Organisation, Mobilisation, and the Role of Russia
}

The Social Democratic working-class movement and its relation to bourgeois organisation and mobilisation were crucial for the process of national and class integration in the early twentieth century. The workers' party, founded in 1899, developed within six years into a huge, markedly agrarian mass movement in which purely political activity nearly eclipsed collective action in the trade unions. In the first parliamentary elections based on universal suffrage, in 1907, the Social Democrats gained 80 of the 200 seats, and their position stabilised during the following decade.

The movement will be analysed in terms of four factors. We will look first at the process of large-scale organisation that occurred at the end of the last century and the beginning of the present. Second, the split among powerholders, both domestic and Russian, that facilitated the movement's initial organisation will be considered. Third, structural and cultural preconditions conducive to strong agrarian socialism will be analysed. And fourth, the part the Russian revolution of 1905 played in determining the role and character of the movement in the process of national and class integration prior to 1917 will be discussed.

In Finland the right to organise into associations, including trade unions that initiated strikes, never became a matter of serious controversy. Mass organisations were formed relatively freely during the late nineteenth century, before the right to establish them was formally acknowledged in 19o6. This tolerance was unusual even in comparison with Scandinavia, where the basic trend was nevertheless similar. ${ }^{1}$ But it was totally different from developments in Western Europe, where industrialisation had occurred earlier. There the idea that anybody, including the propertyless, could organise freely and on formally equal terms to promote common interests in voluntary associations outside the dir-

1 Stenius 1980, p. 198. 
ect control of the state and church was accepted only after a hard struggle, notably in the economic and political spheres. In Britain and several other countries it was principally the trade unions that won, through strikes, recognition of the principle of mass organisation. In nineteenth-century Europe the struggle for the right to organise freely was marked by demonstrations, strikes, and violent encounters with the police and the military. Most Western governments finally made strikes legal between 1860 and 1900, under pressure from organised workers and their parliamentary allies. ${ }^{2}$

In Finland the organisation into voluntary associations was preceded, and partly paralleled, by the revivalist movements of the 1830 and 1840 os and then again in the 188 os and 1890 os. These movements emphatically avoided the registration of their adherents - that is, organisation in the sense of formally constituted associations - but nevertheless, they gathered tens of thousands of people, mainly independent peasants and their offspring, into regular devotional meetings, creating a common identity and unifying structure among the followers. In other words, they organised them. ${ }^{3}$ Because their organisation was based on a direct linkage between individuals and religious leaders, these movements undermined the traditional, corporate relationship that linked the members of an agrarian household to the church through the head of the household or through the village community. They contributed to a process which, according to Reinhard Bendix, is central to the creation of the modern nation-state. When activating members as individuals, they inculcated a sense of solidarity that disregarded traditional intermediate agencies of corporate society, thereby playing a pioneering role in the process of national integration - all the more so as they transcended narrow local boundaries and soon spread over the country (see Chapter 7$)^{4}$

These movements were an expression of the growing self-awareness of the freeholding peasants, whose position and relationship with the gentry and other agrarian groups were changing fundamentally but whose political influence remained small until the Diet resumed meeting in 1863.5 As stated in Chapter 5 , this group allied itself closely with the clergy toward the end of the

2 Bendix 1964, pp. 98-9; Abendroth 1965, pp. 51-62; Tilly 1978, p. 147; Stenius 1977, pp. 8o-2; Stenius 1980, p. 197 .

3 Tilly 1978 , p. 54.

4 Sulkunen 1983, pp. 2, 12-13; Suolinna 1975, pp. 7-11. On the direct linkage of citizens with the state centre as a characteristic of the modern nation-state, see Bendix 1964, pp. 96122.

5 Ylikangas 1979, pp. 275-92. 
century; one indication is that the church soon accepted all revivalist movements. This alliance of course means that the peasantry remained under the church's control, but it also means that religious solidarity toward the church was to be more of an individual matter than before. ${ }^{6}$

The second phase, accompanying the continuing dissolution of the corporate societal system, extended organisation to popular groups other than the independent peasants. The first voluntary organisations grew up in the towns, where fire brigades were founded after the post-Crimean War period of social and economic reforms. The dissolution of the legal bonds of the guild system and the resumption of parliamentary activity had made urban liberals amenable to volunteer fire brigades, for they propagated the new ideal of a respectable and industrious worker and recruited members mainly from artisanal and other lower-middle-class occupations. ${ }^{7}$

On a larger scale, however, mass organisation gained momentum somewhat later, in the 188os and 189os. After the reform of municipal self-government in the countryside (1865) and towns (1873), the local administration represented civil society more adequately than the national political system did. The former was based unambiguously on personal wealth, whereas the latter was based on traditional corporate representation. For the freeholding peasants, the new power in local affairs was accompanied by rapid economic and professional organisation through savings banks, cooperative dairies, and farmers' societies. Elementary schools grew rapidly in the 189 os as well, as did the industrial working class. At the turn of the century nearly half the children of school age attended elementary school. ${ }^{8}$

The first voluntary mass organisation at the national level was the temperance movement, founded in 1883; it remained the largest such group up to the mid-189os, when it had about 8,500 registered members in towns and in the countryside, mainly workers and artisans. It was then overtaken by the youth associations, made up mainly of sons and daughters of the independent peasantry. ${ }^{9}$

Only in 1905 did the Social Democratic party recruit more members than the youth associations or the temperance movement. Moreover, the party, not the trade unions, dominated the working-class movement. 'Unionization and strikes came in the wake of the political organisation of workers', even in

\footnotetext{
6 Cf. Sulkunen 1986, pp. 277-8.

7 Stenius 1980, pp. 203-4, 211-14.

$8 \quad$ Halila 1980 , p. 185.

9 Sulkunen 1977, pp. 53, 73-5, 8o-8; Sulkunen 1981, p. 100.
} 
Tampere, the country's principal industrial centre. ${ }^{10}$ The first serious strikes had occurred late, in 1896 , and during the next ten years trade union activity was concentrated in traditional artisanal and skilled construction occupations. The national organisation was founded only in 1907, after the first Russian revolution. ${ }^{11}$

The membership figures for the three main organisations were not very large even in 1905. In 1902, for example, there were 20,000 members in the temperance movement, 30,000 in the Finnish youth associations, and 8,000 in the Social Democratic party. Trade union activity brought 5,000 to 8,000 adherents, who were largely members of occupation-based sections of party branches. ${ }^{12}$ The importance of these organisations was nonetheless considerable: they represented the advance guard of opposition to the principles of corporate society. In all of them the common people enjoyed formal equality with members of higher strata. This was true even for the trade unions, which included employers until the late 189 os. $^{13}$ In the temperance and youth organisations, positive values linked to God, the fatherland, the emperor, the family, and cultural and material progress dominated. ${ }^{14}$ These groups inculcated a sense of solidarity based on a direct linkage between individual citizens and the national whole, and for their part promoted national integration.

Collective claims gained in importance in the 189os. In the temperance movement this could already be seen in the 188 os, when the movement vehemently attacked the manufacture and sale of alcohol and made drink a central political issue at the local level.

The three movements became increasingly militant, and although this activism was particularly evident in the emerging working-class movement, it could also be seen in other organisations as well. Of great importance was that the emergence of the working-class movement was not followed by a split between it and earlier mass organisations. What mattered most was the conflict between the defenders of the freedom to organise and their opponents, mainly in the bureaucracy: this was the main division. "The working-class movement did not remain alone in its stand. In concrete situations - strikes, prohibition, the franchise reform, the politics of tsarism in Finland - the youth association

\footnotetext{
10 Haapala 1982, p. 235. See also Ala-Kapee and Valkonen 1982, pp. 68-70, $115^{-27 .}$

11 Mattila 1969, pp. 85-8, 118-61, 166-9; Sulkunen 1981, p. 10o; Ala-Kapee and Valkonen 1982, pp. 94-6, 114, 128-9.

12 Sulkunen 1981, p. 100; Mattila 1969, p. 104. The figure for trade unions represents the situation at the turn of the century.

13 Mansner 1981, pp. 32-3; Ala-Kapee and Valkonen 1982, pp. 79-87.

14 Stenius 1977, p. 85.
} 
movement, for example, went largely along the same lines'.15 All principal mass organisations asserted proactive claims, to use Charles Tilly's terminology. ${ }^{16}$

In this controversy influential and even dominant sections of the upper classes defended the right to organise freely. Employers' attitudes toward strikes at the turn of the century were characteristic of the economic elite, who largely accepted the trade union organisation. Although there are parallels with the history of mass organisation in Sweden, Finnish employers tried to restrict the workers' organisation far less than did their Swedish counterparts. Similarly, the Fennoman press opposed attempts to restrict the workers' right to form trade unions. ${ }^{17}$ 'Thanks to the parallel efforts of the government, society, and the industrial workers themselves, the worker question has not taken on here as sharp and gloomy a character as in other countries', said Alexandra Kollontay in her 1903 work on the living conditions of the Finnish workers. ${ }^{18}$

Why did the Finnish upper classes so easily accept the right to organise, even among the workers? Employer discussions of trade unions at the turn of the century provide a clue. Not only was the importance of regulation admitted in labour relations, but also an influential body of bourgeois opinion considered free organisation by workers to be one way to reduce conflicts, believing that mass organisations could eventually help in educating the working class and making it more responsible. Related ideas were cherished among university intellectuals. ${ }^{19}$

This amounts to saying that there existed a belief in the ultimate solidarity of the people, a belief that, before 1905, had not been seriously challenged. Two fundamental facts seem to have contributed to this belief: late industrialisation and the social predominance of an independent peasantry. Only in the 189 os did an industrial working class begin to emerge in urban centres; thus, the main occupations responsible for strikes before the end of the century were artisanal. Second, because the strong freeholding peasantry was a central structural buttress for social calm in nineteenth-century Finland, the mass organisations were not seen as a serious threat.

15 Ibid., 89. According to Hannu Soikkanen (1961, p. 23), 'especially in the countryside the distinction between a worker association and a youth association remained vague [in the 189 os]'. See also Vattula 1976, pp. 49-51, 54, 58, 86, 95. On the links of religious associations with the other early mass organisation in this period, see Heikkilä 1979, pp. 63-84.

16 Tilly, Tilly and Tilly 1975, pp. 51-4.

17 Mattila 1969, pp. 179-83, 19o-1; Stenius 1977, pp. 91-2. Cf. Ala-Kapee and Valkonen 1982, pp. 142, 146, 148.

18 Kollontay 1903, p. 4.

19 Mattila 1969, pp. 19o-1; Stenius 1977, pp. 91-2; Mansner 1981, pp. 40-6; Klinge 1968, pp. 196, 201-2, 206-7; Viikari 1984, p. 38. 
This latter feature may be formulated in more positive terms. The belief in the ultimate solidarity of the people was reinforced by the development of the national movement in the preceding decades. There was a strong faith in the 'peasant folk', those who had given rise to the revivalist movements and were now organising both professionally and economically. This faith undoubtedly facilitated more popular organisation as well, as Francis G. Castles says happened in Scandinavia during this period. There, the emergence of the nascent popular organisations (Castles speaks specifically of the labour movement) coincided with the achievement of influence by the peasantry, which also lent popular legitimacy to the former. ${ }^{20}$ In Finland, with the strong peasant-based national movement, the conditions for mass organisation seem to have been at least as favourable in this respect.

On a more fundamental level, the position and character of the Finnish gentry seems to have been of great importance. As suggested in the previous chapter, the gentry's position not as a landed upper class but as bureaucrats of a dependent state made for a considerable tolerance of demands by other segments of the population for organisation and, finally, even for a popular say in national politics. This tolerance and its linkage to the dominant class's state-making efforts are demonstrated by the relation of the popular organisation to the state. The Finnish mass organisations became strikingly centralised and stable, and only in a few cases did they split into competing organisations. There was no notable tendency toward organisational fragmentation as there was, for example, in Sweden. An important part of the explanation seems to lie in the efforts made from the very beginning by the Finnish elite to tie the organisations to the state. The Fennomans, especially, had an integration strategy that aimed to eliminate all 'sectarian' tendencies in the name of national unity and, at the same time, to establish closer connections between 'Finnish' civil servants and the 'Finnish' people. ${ }^{21}$

The state orientation of the process of popular organisation is another dimension of the main proposition advanced in Chapter 5 - that Finnish nationalism was both a movement for national self-assertion and liberation and a civic religion for the state, and that (somewhat of an exception in small European polities) both middle- and upper-class groups were active in the national movement. The upper classes were attempting to build the state and the nation, and the Fennomans in particular felt it was imperative to do this by linking the emerging civil society to the state. Characteristically, in the old national state, Sweden, the popular organisations were not nearly as close to

20 Castles 1978, p. 14; Alestalo and Kuhnle 1987, pp. 10-11, 21.

21 Stenius 1983. 
the state as in Finland. ${ }^{22}$ The Fennoman attitude may be seen in the rise of the temperance movement. Its expansion was the work of the Fennoman elite, who seized a largely spontaneous activity and attempted to use it to achieve national integration of the workers. Links between the state and the movement were thus deliberately forged. The founders of the local branches included a number of wealthy peasants, but above all included ministers and elementary school teachers, that is, officials of the state church and civil servants. Most of the adherents were artisans and workers. ${ }^{23}$ Also, the first modern mass movement, revivalism, was soon integrated into the church; indeed, several leading figures were ministers.

As stated above, the Fennomans were not the only group active in the process of popular organisation. Connections also developed between other important political organisations and various mass movements. ${ }^{24}$ It was no accident that the temperance movement and other mass organisations were created in the 188 os, the decade in which linguistically based party formation took place within the upper classes.

Besides internal Finnish factors, there was perhaps an external one. In the Western countries that industrialised earlier, strikes and the right to organise had been largely legalised by the time the elites in Finland became aware of the need to regulate relations with the popular masses. Using existing models was natural in a situation in which no serious social conflict seemed imminent: the workers' challenge in Western Europe was known, but it seemed avoidable in Finland. ${ }^{25}$

For all these reasons it is understandable that the mass organisation principle was accepted without extensive agitation by the workers. Yet conditions were different from those not only in Western Europe but also in other Eastern European regions. There, the expansion of similar organisations began later than in Finland. In the Baltic Provinces, for example, they grew up only in the opening decades of the twentieth century (see Chapter 11). In East-Central Europe the obstacles were still greater than in the Baltic Provinces, where the level of popular education was comparatively high. Political organisation of workers was opposed or strictly controlled. As suggested in the preceding chapter, in the East the authority rested more on repressive feudal class domination as such, and the upper classes felt less need to develop national solidarity.

\footnotetext{
22 Stenius 1983, pp. 112-16, 118-23.

23 Sulkunen 1981, pp. 105-6; Stenius 1981, pp. 52-3.

24 Sulkunen 1981; Stenius 1981, pp. 48-58.

25 Soikkanen 1961, pp. 22, 27, 33-4, 37; Alapuro and Alestalo 1973, pp. 88-9, 102. Cf. Sulkunen 1980, p. 39
} 
In short, then, in Finland - and to a lesser degree in Scandinavia ${ }^{26}$ - the working-class movement came to be closely linked to other early mass organisations, emerging from an essentially cultural process of organisation. Where the workers were forced to struggle for their right to organise (that is, in Western Europe), they did so in the context of production, where their common interests crystallised and where they had resources to act collectively. But when large-scale organisation was initiated by the upper classes, as was the case in Finland, it began in the cultural sphere. The open challenge to the political and economic system emerged later, strongly influenced by the early cultural organisation. A third pattern is discernible in other Eastern European countries, where up to World War I all political mass organisation remained under strict control.

Most striking is the linkage between the Social Democratic party and the temperance movement, 'the first mass organisation of the Finnish workers.' ${ }^{27}$ The working-class associations in the 188 os were started under the paternalistic supervision of the employers. By the end of the century, however, the linkage of the working-class movement, which was now gathering momentum, to the temperance movement proved to be organisationally at least as important as that with the paternalistic working-class associations. The openly political arm of the worker movement developed largely from within the temperance movement, which at the beginning of the twentieth century still had a far larger mass base than the party. In the 188 os and 189 os, the temperance movement energetically attacked the production and distribution of drink, and during the last years of the century anti-capitalism became a stronger theme in its collective activism. Political reorientation took place in both the temperance movement and the working-class associations in 1896. In 1898, that is, before the foundation of a nationwide party, the social democratic leaders organised within the temperance movement a so-called strike for temperance, which was supported by about 70,000 people. The aim was to get the masses to support not only prohibition but also the social democratic demand for equal and universal suffrage. For the leading organisers the 'strike' constituted a means to promote the creation of a working-class party, ${ }^{28}$ and this party, which was 'far from socialist', ${ }^{29}$ was founded the following year, at first mainly in towns and industrial centres. Even after the turn of the century the boundary between the party and the temperance movement remained quite vague among party adherents.

\footnotetext{
26 See Lundkvist 1980; Svåsand 1980; Wåhlin 198o; also Castles 1978, p. 13.

27 Sulkunen 1980, p. 39.

28 Sulkunen 1980.

29 Kirby 1971, p. 19.
} 
There was a marked evangelical tinge to the speeches of party agitators, with socialism often called the 'evangel of labor'. ${ }^{30}$ In the mass meetings held in connection with the general strike of 1905 , suffrage and prohibition were often the two central popular demands. The party's prohibition programme was the most radical among the European labour parties, and in 1907, after the introduction of universal suffrage, the party played a decisive role in the passage of prohibition legislation (which came into force only after Finland became independent, however, because the emperor vetoed it). ${ }^{31}$

The temperance movement was not the only mass organisation that facilitated or otherwise marked political organisation by the workers. Often the volunteer fire brigades had the same role as the temperance associations. ${ }^{32}$ Workers also participated actively in the consumer cooperatives that expanded rapidly in the first years of the twentieth century. In 1910 the cooperatives had 87,0oo members, of whom a number were landowning peasants but most were agrarian and industrial workers and crofters. Together with local officials and wealthy peasants, worker representatives often had seats on the governing bodies. $^{33}$ Sports organisations among Finnish workers were also closely connected with the political worker movement - arguably even more closely than elsewhere in Europe - but significantly, the workers' sports clubs were part of a bourgeois central organisation until 1917. In addition, sports were often a key part of the activities of worker associations, very much as in the temperance movement, the youth associations, and the volunteer fire brigades. ${ }^{34}$

In sum, then, by 1905 the working-class movement had only recently and partially separated itself from cultural and economic mass organisations. Ideologically the movement remained vague even after the new party adopted, in 1903 , the Social Democratic label and a definite socialist programme, which was an amalgam of the moderate principles in the 1901 programme of the Austrian Social Democratic party, on the one hand, and the concrete demands in the 1891 Erfurt programme of Karl Kautsky, on the other. ${ }^{35}$ An element of 'left Fennomania' could also be observed in the movement. In the expansion beyond the early core - the industrial working class and the artisans - this orientation was to prove important.

\footnotetext{
$30 \quad$ Kirby 1971, pp. 23-4.

31 Sulkunen 1986, pp. 253-4; Sulkunen 1981, pp. 98-9, 114.

32 Unfortunately, no systematic study exists on the degree of this interconnection, but many local examples can be easily found.

33 Suonoja 1968, pp. 75-7, 136-47.

34 Laine 1983, pp. 379, 484-485, 493-509, 519; Hentilä 1982, pp. 31, 39-44, 48-63.

35 Borg 1965, pp. 63-8.
} 
Another factor that facilitated the emergence of the working-class movement was the conflict between the imperial authorities and the dominant groups in Finland. The 'administrative Russification' at the turn of the century was mild in comparison with what occurred elsewhere, but to the Finnish political class it seemed utterly outrageous and unjustifiable because Finland had enjoyed exceptional economic and cultural florescence and an exceptional degree of internal autonomy. 36

Toward the end of the nineteenth century both the Finnish state and the nation had become increasingly consolidated. Finland had developed most of the characteristics of a self-governing state, with an integrated economy and a high degree of national self-awareness in its upper strata. Not surprisingly, politically active Finns considered their country to be a separate state and were eager to limit the scope of general imperial legislation in Finland. A doctrine was developed and generally accepted which held that in 1809 the Finns had acquired irrevocable constitutional guarantees for the country's autonomy. ${ }^{37}$ At the same time, Russia was slowly modernising and striving to create a more uniform administration. In the 189 os Finland was the only remnant of the areas conquered by Alexander I with a specific status, 'a uniquely privileged position in the Russian Empire. ${ }^{38}$ Centrifugal forces were considered particularly dangerous in view of Germany's rise in Central Europe. It became increasingly clear to the imperial government that Finnish autonomy was incompatible with Russian autocracy and that, for reasons of security in the St. Petersburg and Baltic regions, Russia was obliged to defend her national interests in Finland without compromise. After all, the south-eastern border of Finland lay only about twenty miles from the Russian capital. ${ }^{39}$

In 1890 the Finnish postal system was incorporated into that of the empire without the consent of the Finnish estates. The conflict really broke out, however, in 1899 with the integration of Finland into the empire's general system of military service. In order to force this plan through, the emperor reserved for himself, in the February Manifesto of 1899, the right to determine the final form of all legislation for Finland in matters of 'general Imperial concern', while the

$36 \quad$ Thaden 1981a, pp. 7-8; Thaden 1981c, p. 462; Polvinen 1984, pp. 342-4.

37 Jussila 1979a; Jussila 1984, pp. 98-9; Schweitzer 1978, pp. 4-5, 18-30; Thaden 1984, pp. 91, 211-12, 229-30.

38 Pipes 1964, p. 4.

39 Polvinen 1984, pp. 52-7; Jussila 1979b, pp. 31, 35; Lundin 1981, pp. 357-8, 373; Thaden 1981b, p. 76 . 
Finnish Diet only had the right to give its opinion. ${ }^{40}$ From a strictly legal point of view the manifesto did not greatly change the character of Finno-Russian relations. But the flexibility of the earlier period had made the Finns overconfident about the separate status of their country, and consequently the manifesto was unanimously felt to be a glaring injustice. The estates were brought back to earth'41

Several measures integrating Finland more closely into the Russian Empire were carried out by 1905. In 1900 the Language Manifesto extended the use of the Russian language in the administration, particularly at the expense of Swedish. The Russian system of conscription was extended to Finland in 19o1; it was followed by passive resistance. The actual consequences for the great majority of the people were minimal, thanks partly to the effectiveness of the 'army strikes', whereby conscription into the Imperial Army was dodged. But the extension of the scope of general imperial legislation remained highly offensive to the Finnish political class. ${ }^{42}$

The Finnish upper classes reacted immediately, in 1899, by looking - for the first time - for popular support to counter the Russian demands. Several petitions were collected, the largest of which, the so-called Great Address, contained 522,00o names, representing more than one-fifth of the total population in 1899. The first Finnish reaction was unanimous, but soon the bourgeois groups adopted different attitudes toward the Russian demands. The Finnish party of the Fennomans (or the Old Finns, as they were generally called), in line with its earlier policy, followed a course of compliance or appeasement, whereas the Swedish party and the liberal Young Finns adopted a policy of passive resistance, forming the constitutionalist bloc. A coalition across the language boundary emerged, and party strife became increasingly tense, connected directly to cooperation or non-cooperation with the imperial authorities. ${ }^{43}$

The constitutionalist Young Finns now sought the support of the workingclass movement, in which they had been active during the 189os: now the Young Finnish Left unconditionally backed the right to strike and in certain cases also supported universal suffrage, the first and foremost goal of the working-class movement. At the same time a strong faction within the workers' party itself sought cooperation with the Young Finns. The introduction to the 1899 party programme specifically stated that the preservation and protection of Finland's national independence was an essential condition for gaining economic and

40 Thaden 1981b, p. 82; Polvinen 1984, pp. 108-9.

41 Jussila 1979b, pp. 37-8. See also Polvinen 1984, pp. 110-11.

42 Jussila 1980; Lundin 1981, pp. 439-40.

43 Paasivirta 1981, pp. 176-7; Thaden 1981c, p. 46o. 
social liberties. The party considered itself 'patriotic and national, but not chauvinist'. In many worker associations in both the countryside and small towns, these early years were marked by a struggle for control between the socialists and the remaining bourgeois radicals, and relations with other parties were relatively close. Some of the Social Democratic leaders and many workers even actively resisted the Russians under the leadership of bourgeois radical groups that had split off from the constitutionalist bloc in 1904. ${ }^{44}$

The working-class movement was treated with sympathy by the opponents of the Young Finns as well. In 1904-6 the Old Finnish Left approached and to a certain extent joined with the Social Democrats. The Fennoman love of masses' was revived even before the Russian crisis finally spread to Finland in the autumn of 1905. In June of that year, the Old Finnish party accepted the principle of universal suffrage, though not the need for a unicameral assembly. ${ }^{45}$

The Russian pressure on the bourgeois parties and their deep internal divisions evidently provided some leeway for the working-class movement, which was able to press for its central demands more forcefully and to differentiate itself from the bourgeois parties more sharply than before. The working classes increasingly felt that the resistance was being engineered by the Finnish ruling classes as a means of protecting their own interests. The effects of Russification were felt most keenly by the professional and educated classes, whereas the workers were not so directly affected. Although passive resistance promised franchise reform once the threat to Finnish liberties had been averted, the working-class movement increasingly rejected this order of priorities. ${ }^{46}$ This considerable freedom of activity vis-à-vis the bourgeois parties soon made the party's line more independent and tenacious, though by no means revolutionary.

Not surprisingly, the imperial authorities were favourable to the rather small labour party, considering it less dangerous than the more restive bourgeois groups and even hoping to use it against them. The Russians also tried to drive a wedge between the Finns by proposing social reforms, which they thought would strengthen popular allegiance to the empire. ${ }^{47}$

To conclude, the various interests, both Finnish and Russian, having a share in the Finnish government came into conflict. The cleavage led different groups

\footnotetext{
44 Paasivirta 1981, p. 189; Jussila 1979b, p. 25 (quotation), pp. 50-1; Kirby 1971, pp. 19, 21, 25.

45 Stenius 1981, p. 63; Paasivirta 1981, pp. 189-9o.

46 Kirby 1971, pp. 29-30. Cf. Paasivirta 1981, p. 182.

47 Polvinen 1984, pp. 287-301; Jussila 1979b, pp. 24, 39-40, 49, 171-2. Cf. Rasila 1961, p. 193; Lundin 1981, pp. 429-33.
} 
of powerholders to seek the support of the emerging working-class movement, or at least to accept it. The situation is familiar: when a split develops among the dominant groups, some of them seek support from popular groups. This pattern has frequently preceded revolutionary situations (for more detail, see Chapter 8), but it has also paved the way for the non-revolutionary extension of political rights. Developments in Finland prior to 1905 point clearly to the latter situation. The workers' party took shape, consolidated its position easily, and remained moderate.

There was one potentially dangerous development for the indigenous dominant groups, however. Heretofore the empire had remained the ultimate guarantor of overall stability in the grand duchy. In addition, the Finnish powerholders controlled a national armed force. In the new situation, however, not only did imperial support become uncertain, but also, in consequence of the new system of military service, the domestic troops were disbanded. In 1901-5 all Finnish units were gradually dissolved, and the Finnish state was left without a coercive apparatus of its own other than the police.

\section{The General Strike of 1905, Parliamentary Reform, and the Rise of} Agrarian Socialism

The revolutionary situation in Russia extended into Finland in October 1905. Earlier that year demonstrations and other protests were limited to the towns, and no violent events comparable to those in the Baltic Provinces, for example, took place. ${ }^{48}$ Even the Russian general strike of October reached Finland only after ten days, despite the proximity of St. Petersburg. But when it finally spread to the grand duchy, it led to substantial mobilisation in both towns and countryside. The strike in Finland began in a national and patriotic spirit, with the constitutionalists and the Social Democrats working together in many towns. As the strike progressed, however, the differences between the two factions grew. Both agreed on the need to reverse the Russian integration policy, but the bourgeois groups and the imperial authorities opposed the Social Democrats' demand for universal suffrage and a unicameral assembly. ${ }^{49}$

The situation was revolutionary in important respects. During a short but decisive period, the government, which had previously been under the control of a single polity, became the object of effective, competing, and mutually

48 Jussila 1979b, pp. 58-6o.

49 Jussila 1979b, pp. 74-86; Kirby 1971, pp. 49, 58. 
exclusive claims by two distinct polities - to use Charles Tilly's definition of a revolutionary situation. ${ }^{50}$ The Social Democrats were able to push through their demands for universal suffrage and a one-chamber legislature because the state was paralysed, first by the inability of the autocracy to call on the police and the armed forces, and later by the necessity to fight other enemies within the empire. The crisis resulted in the working-class movement being able to access the polity. The creation of an unofficial armed militia in the first few days of the strike also indicates the state's paralysis. Both the bourgeois civil guards and the Red Guards, which were linked with the worker movement, evolved from the militia. Some of the guards remained in existence well into $1907 \cdot{ }^{51}$

The emperor authorised the transformation of the political system on 4 November 1905, together with the suspension of the February Manifesto, the conscription law, and other integration measures. The new political system was confirmed the following year by the estates, under pressure from the socialists. The estates were replaced by a unicameral assembly based on universal and equal suffrage for both men and women. Finland thus experienced 'Europe's most radical parliamentary reform', in which 'Europe's most conservative estate-based Parliament' was superseded by 'the most democratic' system in the whole Continent. ${ }^{52}$ The great leap from the corporate conception of representation to one based on the individual was made all at once, whereas elsewhere this fundamental change took at least several decades. ${ }^{53}$ True, there was an essential constraint: the final decision on legislation remained in the hands of the emperor. In the old system only a few thousand persons had had a voice in choosing representatives to the noble and clerical estates, and the latter was the last of its kind in Europe. In the two other estates, those of the burghers and the freeholding peasants, the electoral basis was much larger, but still the reform multiplied tenfold the number of qualified voters from 126,ooo to $1,273,000$.

The Russian autocracy had guaranteed the quasi-immutability of an antiquated system of corporate representation. Its temporary collapse led in one stroke to a fully democratic electoral system. This sudden extreme leap was intimately bound up with fluctuations in the strength of the imperial authority.

\footnotetext{
$50 \quad$ Tilly 1978 , p. 191.

$5^{1}$ On the guards, see Jussila 1979b, pp. 116-39; and Salkola 1985, 1: 45-7.

52 Quotations are from, respectively, Jutikkala and Pirinen 1962, p. 242 (cf. Rokkan 1970, pp. 84-5); Wirilander 1974, p. 21; and Lundin 1981, p. 445. See also Allardt 1981a, pp. 623 .

53 Bendix 1964, pp. 112-22.
} 
TABLE 8 Distribution of seats in Parliament won in Finnish general elections, 1907, 1916, and 1917

\begin{tabular}{lrrr}
\hline Parties & $\mathbf{1 9 0 7}$ & $\mathbf{1 9 1 6}$ & $\mathbf{1 9 1 7}$ \\
\hline Social Democratic party & 80 & 103 & 92 \\
Agrarian Union & 9 & 19 & 26 \\
Finnish party & 59 & 33 & 32 \\
Young Finnish party & 26 & 23 & 24 \\
Swedish People's party & 24 & 21 & 21 \\
Others & 2 & 1 & 5 \\
Total & 200 & 200 & 200 \\
National turnout & $70.7 \%$ & $55.5 \%$ & $69.2 \%$ \\
\hline
\end{tabular}

SOURCE: ÉLECTIONS POUR LA DIÈTE EN 1917 1919, 13, 41-2

In the first general elections, in 1907, the turnout was 71 percent - a figure not surpassed until 1945 - and the Social Democrats gained more than one-third of the vote. With 80 of the 200 seats in Parliament, they became the largest socialist party in Europe (Tables 8 and 9). In agrarian Finland this achievement necessarily required enormous rural support, and indeed, the party received almost nine-tenths of its votes from the countryside. Rural voters were in the majority even in relative terms: the Social Democrats received 34 percent of the urban vote and 38 percent of the rural vote. The success was spectacular, exceeding to some degree even the party's own expectations. ${ }^{54}$ Among the bourgeois parties, the Old Finnish party gained a much larger vote than the Young Finns. The former was supported mainly by the independent peasants and the Finnish-speaking educated class, the latter by middle-class groups in both towns and countryside (see Chapter 7). The Swedish party (now the Swedish People's party) received nearly all the Swedish-speaking vote in the coastal areas. Unlike the other parties, the populist Agrarian Union emerged only after suffrage reform in 1906. It was markedly more radical than the other bourgeois parties and was supported above all by the smallholders. Like the Social Democratic party, the Agrarian Union was able to rest on earlier mass organisations - the youth associations and, in some regions, the professional farmers' societies. At first, however, it grew only slowly. 
TABLE 9 Rural and urban party support in Finnish general elections, 1907, 1916, and 1917

\begin{tabular}{|c|c|c|c|c|c|c|}
\hline \multirow[b]{2}{*}{ Parties } & \multicolumn{3}{|c|}{ Countryside } & \multicolumn{3}{|c|}{ Cities } \\
\hline & 1907 & 1916 & 1917 & 1907 & 1916 & 1917 \\
\hline Social Democratic party & $38 \%$ & $48 \%$ & $45 \%$ & $34 \%$ & $44 \%$ & $45 \%$ \\
\hline Agrarian Union & 7 & 11 & 15 & o & $\mathrm{o}$ & o \\
\hline Finnish party & 29 & 18 & \multirow{2}{*}{$3^{2^{\mathrm{a}}}$} & 20 & 14 & \multirow{2}{*}{$34^{\mathrm{a}}$} \\
\hline Young Finnish party & 14 & 12 & & 13 & 14 & \\
\hline Swedish People's party & 11 & 10 & 7 & 26 & 25 & 19 \\
\hline Others & 1 & 1 & 1 & 7 & 3 & 2 \\
\hline Total & $100 \%$ & $100 \%$ & $100 \%$ & $100 \%$ & $100 \%$ & $100 \%$ \\
\hline $\mathrm{N}$ (thousands) & $77^{\circ}$ & 690 & 840 & 121 & 111 & $15^{8}$ \\
\hline National turnout & $69.6 \%$ & $56.8 \%$ & $69.5 \%$ & $72.7 \%$ & $49.0 \%$ & $67.9 \%$ \\
\hline
\end{tabular}

a Because of party alliance between the Finnish party and the Young Finnish party, their respective votes cannot be distinguished in the 1917 elections.

SOURCES: ÉLECTIONS POUR LA DIÈTE EN 1907 ET 1908 1909, 8; ÉLECTIONS POUR LA DIÈTE EN 1916 1917, PP. 42-9; ÉLECTIONS POUR LA DIÈTE EN 1917 1919, 16, PP. 38-9

The most important and unique feature of the enormous mobilisation in 1905-7 was the rise of agrarian socialism. True, there were certain similarities with the Baltic Provinces in 1905, as will be seen in Chapter 11. Comparisons with some rural regions in Italy and France can also be made. ${ }^{55}$ But as an organised phenomenon that spread throughout the entire country, Finnish agrarian socialism is unique. How can the strong agrarian base of the Social Democratic movement be explained, and how did it affect the movement's overall character?

As to the first problem, a number of significant structural factors can be identified. Obviously the agrarian response was linked to the fact that the landless population, forced to remain outside the traditional agrarian community, had grown rapidly at the end of the nineteenth century. At the same time, the leasehold question also emerged, with crofters trying to defend themselves against the increasingly market-oriented landowners (see Chapter 3 ). These two developments created a foundation for the rise of agrarian socialism. Yet they alone are insufficient to explain either the strength of the movement or its relatively high level of organisation. Eric Wolf has emphasised that the success of peas- 
ant movements depends not merely, or even primarily, on the grievances of the participants, but on the connections between the agrarian groups and other, non-agrarian groups. 'Poor peasants and landless laborers ... are unlikely to pursue the course of rebellion, unless they are able to rely on some external power to challenge the power which constrains them, ${ }^{56}$ It may be argued that in Finland such an external power existed and that it was made up of, to an exceptionally high degree, the industrial proletariat, or, rather, its party, the Social Democrats. As discussed earlier, the capitalist transformation in Finland took place simultaneously in industry and agriculture. Hence, both the industrial and the agrarian proletariat increased at roughly the same time. Moreover, an exceptionally close link seems to have developed between the two groups, because the industries were mostly located in the countryside, seasonal work was common, and the overwhelming majority of the industrial workers had come directly from agrarian occupations.

It has been argued, to be sure, that the prevailing conditions hampered, rather than helped, the political organisation of the working class. It was difficult, so the argument runs, for the new ideas advanced in the workers' associations to percolate into isolated rural communities. In addition, industry itself was young, and because the workers had been in industrial employment for only a short time, they were still influenced by traditional agrarian values. Finally, because employment was seasonal and the level of skill required generally low, a sense of solidarity was difficult to create. ${ }^{57}$

This argument, however, focuses exclusively on the industrial workers. From the perspective of agrarian workers, the situation appears very different. After all, there is nothing peculiar in the radicalisation and organisation of the industrial working class. The process in Finland followed much the same pattern observed in several other European countries, even though the dispersion of Finland's main industries throughout the countryside may have retarded it. The real point is that Finnish conditions facilitated, to an exceptionally large extent, the radicalisation of the agrarian workers, and therefore of the great majority of the working class. The situation furthered the rise of class consciousness in the agrarian proletariat, making it easier for the industrial and agrarian workers to forge an alliance.

Moreover, these conditions apparently facilitated the incipient radicalisation of the crofters as well, or at least tended to shape the political form their already manifest but not yet crystallised grievances were to take. Crofters had

$5^{6} \quad$ Wolf 1969, p. 29 o.

57 Soikkanen 1961, p. 5 . 
been the first to express their discontent in the countryside (Chapter 3), and their strikes multiplied in the years immediately preceding the general strike of 1905. Likewise, they were the only group that indisputably dissociated itself from the bourgeois-led national protests against the Russian integration measures at the turn of the century. Crofters were reluctant to sign the Great Address in 1899, and they took part in the 'army strikes' only passively. 58

The previous institutional, organisational, and cultural connections between town and country also seem to have played a part in forging the political alliance between them. The most important links were provided by the expansion of the elementary school system and the earlier process of mass organisation. Of the members of the temperance movement, which originated in the towns, one-half lived in the countryside at the end of the last century, and subsequently the proportion of rural members increased considerably. The proportions in the volunteer fire brigades were more or less similar. ${ }^{59}$ Common organisational frames presumably facilitated the passage from common interests to explicit political organisation encompassing both towns and countryside especially because the industrial working class was still weakly structured and therefore without a strong working-class culture. ${ }^{60}$ Various cultural activities theatrical and musical performances, social evenings, athletic events, and so forth - played a central role in the working-class associations, as they did in the temperance movement and the volunteer fire brigades. Indicative of the link or, rather, the continuity is also the fact that the temperance movement began to lose members rapidly as the Social Democratic party expanded after $1905 .{ }^{61}$ This cultural connection helped to link the rural and urban poles in the worker movement, all the more so as the face-to-face relationship between agrarian workers and crofters on the one hand and their employers on the other bore little resemblance to the collective conflict between worker and employer in the industrial centres.

In these respects Finland differed from other Eastern European countries. First, although Eastern Europe too had a large landless proletariat, no sectors other than minor groups in the intelligentsia allied themselves with it. There, it was not until the upheavals of World War I that the rural proletariat was

$5^{8} \quad$ Ibid., pp. 345-8; Tommila 1967, pp. 150-6o; Jutikkala 1970.

59 On the temperance movement, see Sulkunen 1986, p. 106. In the 188 os the number of rural volunteer fire brigades already exceeded that of urban brigades (Stenius 1981, p. 23), even though the number of urban firefighters was presumably greater at that time. Later, moreover, the number of rural brigades grew many times over.

6o Alestalo 1977, pp. 109-10.

61 Sulkunen 1981, p. 114. 
radicalised. As feudal relationships between the landless and the landlords disintegrated, they were only slowly replaced by new class relationships. Landless and poor peasants may have been freed from the old, but they were not integrated into the new. Consequently, the peasant movements were mainly outbursts lacking clear political organisation. ${ }^{62}$ Second, no popular organisational network covering both town and country existed in Eastern Europe prior to the emergence of the worker movement.

Structural and institutional factors appear to have created conditions favourable to the Finnish Social Democrats. But the nature of the crisis of 1905 - that is, immense mobilisation and subsequent parliamentary reform - was decisive. The Social Democratic party was the only political movement with an organised mass base when the general strike extended into Finland. The previous stability of the political system had meant that other political groupings were formed almost completely within the dominant groups. In 1905 different grievances were suddenly fused within the organisational framework of the Social Democratic party. A link was forged between the early adherents in urban centres and new adherents in the countryside, and also between a number of intellectuals who joined the party and the great agrarian mass. Now an originally urban and industrial-based organisation could directly mobilise large agrarian masses, a fact which Joel S. Migdal, Theda Skocpol, and others maintain is crucial in explaining the rise of political movements among peasants. As in a number of Third World countries, a political movement gaining extensive peasant support was created in Finland as the result of an impetus originating outside the peasantry. ${ }^{63}$ But in Finland the factors discussed above contributed to the fact that the urban-rural alliance took shape very rapidly and on an exceptionally large scale.

The spread of worker associations at the beginning of the century indicates both the leading position of the industrial proletariat and the link between town and country. The associations were first established in big towns, then in smaller towns and industrial and commercial centres in the countryside, and finally in the countryside itself. Rural associations were first set up in key villages in the communes and near sawmills and railway stations. With the general strike the focus of the labour movement shifted away from the towns to the industrial centres in the countryside and an agrarian setting. ${ }^{64}$

Agrarian workers joined the party in large numbers. In this atmosphere the Social Democrats were able to attract support from the crofters as well, indeed

62 Galaj 1974, pp. 322-6; Chirot and Ragin 1975; Erényi 1975, pp. 57-61.

63 Migdal 1974, pp. 231-6; Skocpol 1982, pp. 361-7.

64 Soikkanen 1961, pp. 183, 202, 340. 
becoming the only party able to create a noteworthy crofter organisation. ${ }^{65}$ Party membership went from 16 , ooo to 45 ,0oo in 1905 , and to 85 , ooo by the end of 1906. In October of 1906 membership rose to 107,00o, but after that it began to decline; in 1910 membership stood at 52,00o. In 1906 the Social Democratic party was the strongest socialist party in the world in relative terms, and 69 percent of its members were from the countryside. Between 1904 and 1906, moreover, the number of worker associations increased tenfold, from about 100 to nearly $1,000 .^{66}$

All in all, the Finnish situation obviously provides support for Eric Wolf's contention about peasant revolutionary activity: 'It is probably not so much the growth of an industrial proletariat as such which produces revolutionary activity, as the development of an industrial work force still closely geared to life in the villages'.67 In Finland conditions were favourable for common mobilisation and collective action by the agrarian and industrial working class. But a short-term factor, the Russian revolution of 1905 , activated them.

How did the large agrarian response affect the overall character of the movement? First, and understandably enough, the huge rural majority in the party based much of its action on local traditions. The worker movement became distinct from the other popular organisations, but generally the relations with these latter remained reasonably good or even close. The sites for cultural and political activity were the workers' halls, constructed jointly by the members and arguably the most peculiarly Finnish phenomenon in the whole movement. ${ }^{68}$ In this period 'the working-class movement was to a large extent a cultural movement, with the workers' halls as its centres' ${ }^{\prime} 9$ They were a major factor behind the cohesiveness of the movement: the party functioned above all 'as the organisational, political, and ideological bond linking the network of workers' halls. ${ }^{70}$ The number of halls rose from 47 in 1905 to 683 in 1910, and to 940 in 1916, with social evenings, various performances, and contests occupying a central place in their utilisation. Although the working-class movement now increasingly distinguished itself from other mass organisations, its internal division of labour was modest. Actually - and again, understandably political, economic, and cultural aspects were not really differentiated. ${ }^{71}$ Seen

\footnotetext{
65 Rasila 1961, pp. 309-11, 412.

66 Soikkanen 1961, pp. 338, 340; Soikkanen 1978, p. 354.

67 Wolf 1969, p. 292.

68 Hentilä 1982, p. 48.

69 Hako 1974, p. 143 (quotation); Hentilä 1982, pp. 47-8. Cf. Alestalo 1977, pp. 98-106.

$70 \quad$ Kettunen 1984, p. 39.

71 Ibid.; Hentilä 1982, pp. 47-8.
} 
from this perspective, William C. Martin's conclusion seems only a little exaggerated: 'The educational activities of the Workers' Party carried the ideas of nationalism outside the literate classes and effectively created a national consciousness among urban workers and landless rural workers'. ${ }^{72}$ It is evident that the large agrarian response that assured the labour movement's penetration into the polity influenced the movement in a reformist direction. This is certainly not unique as such, ${ }^{73}$ but the scale of agrarian support was without parallel, and so too was its overall impact on the worker movement. In 1913 J.K. Paasikivi, a leading Old Finnish politician and later a president of Finland, thought that, with time, the Social Democrats presumably would develop into a 'radical progressive party'. ${ }^{4}$

Second, rapid and powerful penetration into the polity made the Finnish working-class movement focus on the state rather than on direct confrontation with the capitalist class. ${ }^{75}$ Before 1905 both the political movement and the trade union movement were undeveloped in comparison with Western Europe. The first Russian revolution brought about a complete and easy victory in the political sphere, but the relations between workers and employers in such an agrarian country as Finland were not greatly affected. Unlike Sweden in 1902, for example, Finland's strike for the franchise was not a manifestation of the power of organised labour. That is, rather than being an internal encounter based on resources arising directly from organisation within the production process, ${ }^{76}$ it was a direct result of the country's political dependence.

Strike activity increased temporarily between 1905 and 1908; in other words, it took a political crisis to bring about expansion of the trade union movement. In 1907 both the national trade union organisation and the national employers organisation were founded, but these played only a limited role. The employers did not really recognise the right of organised labour to bargain, and the trade union movement soon adopted the role of a sort of mediator, viewing labour conflicts in a narrow economic perspective. ${ }^{77}$ From 1907 to 1916 the membership figures of the national trade union organisation varied between 30 and 60 percent of the Social Democratic party's membership; in the Western countries, in contrast, the ratio was usually the inverse, with the trade unions

\footnotetext{
72 Martin 1970, p. 320. See also Hamalainen 1978, pp. 30-1.

73 Take France, for example; see Gallie 1982, pp. 169-72.

74 Paasikivi 1957, p. 180.

75 See Kettunen 1979, pp. 71-98; Alestalo 1977, pp. 103-6; Hodgson 1974a, p. 3 .

$76 \quad$ Hentilä 1979, pp. 127-36; Kettunen 1979, p. 79.

77 Kettunen 1979, pp. 92-3; Mansner 1981, pp. 8o-2, 101-16; Ala-Kapee and Valkonen 1982, pp. $273-8$ o, 322-5, 337-40.
} 
serving as the backbone of the labour movement. Even among the industrial proletariat, trade union organisation lagged behind political organisation. ${ }^{78}$ Therefore, although it is true that the political and economic spheres were not really differentiated, nonetheless, the political was much more in evidence. Characteristically, in the countryside trade union activity was normally incorporated into the activities of the worker associations, sometimes in separate occupation-based sections. ${ }^{79}$

The relationship between politics and trade union activity resembles in some respects what Edward Shorter and Charles Tilly have, in their analysis of strikes in France, called 'sparkplug unionism' ${ }^{80}$ In new industries and semiskilled worker occupations that entirely lacked collective traditions and habits, activity was directed at the central forum of national politics as much as at local problems, which, for their part, were above all economic bread-and-butter issues. At the local level a weak union organisation was run by 'sparkplug' militants, an organised nucleus that sparked strike activity. At the national level union activity was in the hands of radical political parties and industrial federations. The solidarity born of sparkplug unionism was usually short-lived: the participants in collective disputes quickly lost interest and drifted back to work. In Finland, workers who were active in unions and strikes lacked traditions of collective action; the entire industrial working class had only recently come from an agrarian base, and the just-created unions owed their expansion to a great political crisis. (In France, sparkplug unionism exploded in 1936, after the stunning electoral victory of the parties of the Left.) Locally, economic demands predominated, and strikes were organised by militants who often acted quite independent of the central organisation..$^{81}$ What mattered nationally was politics, if only because at that level the working-class movement really had a say, whereas at the local level it had none.

If the class experience is seen as determined by productive relations, and if class consciousness is the way in which these experiences are handled in cultural terms, ${ }^{82}$ the two display rather loose links in the Finnish case. In Finland the 'political' class struggle was not based on the 'economic' one. ${ }^{83}$ This situation resulted, however, more from the extraordinary extensiveness of the political organisation than from the weakness of the trade unions. As a matter

\footnotetext{
78 Kettunen 1979, pp. 71-6; Ala-Kapee and Valkonen 1982, pp. 230-8.

79 Ala-Kapee and Valkonen 1982, pp. 111, 124, 243-51.

8o Shorter and Tilly 1974, pp. 127-37, 181, 217.

81 Ala-Kapee and Valkonen 1982, pp. 20o-8, 26o-9, 301-37.

82 The formulation is E.P. Thompson's (1963, pp. 9-10).

83 Kettunen 1980b, p. 6.
} 
of fact, the trade unions recruited as many workers as could be expected in a country with so few industrial centres. ${ }^{84}$ Internal factors - the degree and character of industrialisation - set an upper limit on the trade union organisation, but they did not restrict political organisation, the upper limit of which was determined by Finno-Russian relations.

This specific opportunity structure resulted in collective action different from that in the major Western countries and in Scandinavia. The trade unions were above all auxiliary instruments of the party. The movement's strength lay in its electoral success, not in its capacity for concerted mass action, notably strikes. The party's whole organisation was geared to secure votes in elections, and the typical voters were by no means actual or even potential trade union members: they were agrarian workers or crofters whose relations with their employers were largely traditional and whose political activities were concentrated in the local workers' hall. The only way for them to voice their opinion was to vote in national elections; the local administration remained as before.

In practice the movement grew into a large parliamentary party, with some intellectual leaders, mainly Old Finns who had joined the party in 1905-6; with over a dozen local newspapers; and with a large number of functionaries who concentrated entirely on the electoral work. The Red Guard, which had been formed during and after the general strike of 1905, was disbanded by the party leadership prior to the first elections, in compliance with the Finnish government's suspension order. ${ }^{85}$ The parliamentary orientation was certainly not weakened by the fact that the Finnish Social Democratic party was the first and only socialist party in the world to attain an absolute majority before the Russian revolution of 1917. Typically, very few official contacts existed between the Finnish party and the Russian revolutionaries. ${ }^{86}$

In theory the party was revolutionary, awaiting the struggle foreshadowed by the events of 1905 and building up its strength. It paid little attention, however, to how the revolution was to be achieved and what its substance was to be. It was generally believed that a revolution in Russia would produce a bourgeois democracy and that the immediate task of the Finnish Social Democrats would then be to press for a more democratic form of government. Consequently, the socialists came to visualise their party more and more as the leading protagonist in the struggle for democracy, and the meaning of revolution remained extremely vague. ${ }^{87}$

84 Cf. Kettunen 1986, pp. 73-81.

85 Salkola 1985, 1:47; Soikkanen 1961, pp. 246-8.

86 Kirby 1970.

87 Kirby 1971, p. 125; Jussila 1979b, pp. 170-1; Hodgson 1974b, pp. 22-4. 
Aware that their chances to act were fundamentally dependent on developments in Russia, the Social Democrats came to accept a role of 'class-conscious revolutionary passivity' ${ }^{88}$ The party combined revolutionary rhetoric and reformist practice much as the German Social Democrats did, and Kautsky was indeed the master theoretician for Finnish socialists as well. In contrast with the German movement, however, the backbone of the Finnish movement lay less in the collective organisation of the workers and more in the individual voting behaviour of the party's followers, the great majority of whom were engaged in agriculture. For them the idea of revolution certainly remained much more vague than for party activists.

To conclude, the working-class movement became a powerful instrument for both class and national integration. True, the events of 1905 had bred some familiarity with a revolutionary situation and a diffuse belief in the coming of revolution. But the class conflict was limited, as is reflected in the primacy of parliamentary activity and the rooting of the movement in the general process of mass organisation. In addition, the movement had a pronounced cultural and even national orientation, most obviously at the local level: the worker associations were part and parcel of the rapidly expanding local organisational network, which contributed to a vision of Finland as a political and cultural entity. At this level the labour movement was basically a way of linking the workers with the emerging civil society. Even the great strike of 1905 was important in this respect: as a powerful catalyst in the 'nationalisation' of political life. ${ }^{89}$

The imperial authorities in Finland never seriously doubted the reformist character of the movement. In 1907 administrative Russification was reintroduced, but unlike in the Baltic Provinces there was no repression, and the actual impact had scarcely gone beyond its initial stages by $1914 .{ }^{90}$ Even after the Social Democrats' spectacular success in the elections, the Russians were much more alarmed by small bourgeois groups thought to be advocating separatism than by the Social Democrats. ${ }^{91}$ Still, the restrictions the imperial authorities imposed enhanced the national orientation of the labour movement. In the Social Democratic opposition to Russian autocracy, national and class aspects were necessarily linked..$^{92}$

\footnotetext{
88 Kirby 1971, p. 129 (quotation); Kettunen 198ob, p. 13.

89 Cf. Tilly, Tilly and Tilly $1975,53-4$.

$90 \quad$ Thaden 1981a, 11; Thaden 1981c, 459.

91 Jussila 1979b, 171-80.

92 Esp. Jussila 1979b, 226-9, 240.
} 